\title{
Margaret McCartney: Religion must defy the harms of futile medicine
}

\author{
Margaret McCartney general practitioner
}

Glasgow

Doctors are "murderers," the UK has "death panels," and the plight of Alfie Evans and his family shows why we say we need guns to protect us from the government. ${ }^{1}$ Social media in the age of fake news can be dangerous. This becomes more bizarre when tethered to the view, especially from the far right and self identified Christians in the US, that Alder Hey Hospital is committing a heinous crime. Catholicism in particular was behind pleas for more, non-palliative, intervention in the life of Alfie Evans, a baby with a fatal illness who has now died.

I went to a Catholic state school, a common destination for children my age brought up in Scotland. I clearly remember fund raising efforts to help open a hospice. It was clear that death was part of life, medicine can't make us immortal, and dying should have dignity. Indeed, Cicely Saunders, founder of the hospice movement, was Christian and used her values to create her legacy. Care of dying people has been a feature of many religions that acknowledge humans' impotence in our ultimate mortality - and our ability to care for each other despite it.

I'm an atheist, and I find the intersection between religion and day-to-day medical practice fascinating and troubling. Some patients and families are left believing that, unless they ask or plead for every possible intervention, their actions are somehow anti-religious and ungodly. I accepted an invitation to join the Lancet-Mario Negri-Vatican commission earlier this year because I believe that the intersection of faith and evidence based medicine could be much improved.

In end-of-life matters, many religions offer a far more reflective and careful assessment than is commonly promulgated. For example, Pope Francis said in 2017, "And even if we know that we cannot always guarantee healing or a cure, we can and must always care for the living, without ourselves shortening their life, but also without futilely resisting their death. This approach is reflected in palliative care, which is proving most important in our culture, as it opposes what makes death most terrifying and unwelcome-pain and loneliness."

But this was not the message people heard from the Vatican. If religion meant that patients must take futile treatments and families should insist on them, not only would this become unethical for doctors-administering inappropriate interventions with a burden of treatment to be endured and no potential benefit-it would also mean that no one would be allowed to die peacefully. All would have to undergo ineffective cardiopulmonary resuscitation, chemotherapy, or surgery. It would be absurd and cruel.

Religious organisations must stand against the suffering inflicted by medicine administered simply because it can be

Yet a sect in the US somehow thinks it righteous to instruct treatment beyond hope, while seeing a child not as an individual with rights distinct from the parents but as a conduit for the expression of a belief system.

We all come with biases, experiences, fears, and hopes. Religious faith clearly sustains and nourishes many people. But it can also, when misinterpreted, dressed up with fake news and social media hyperbole, create a climate where citizens think that religion justifies false hope and attacks on families and staff caring for people at the end of life.

Religious organisations must stand against the suffering inflicted by medicine administered simply because it can be. They should ensure that their followers understand their message - and correct it vocally when they do not.

Competing interests: See www.bmj.com/about-bmj/freelance-contributors/margaretmccartney.

Provenance and peer review: Commissioned; not externally peer reviewed.

1 Burton TI. The controversy surrounding the death of British toddler Alfie Evans, explained. Vox 28 April 2018. https://www.vox.com/policy-and-politics/2018/4/27/17286168/alfieevans-toddler-uk-explained.

2 Pope Francis to the European Regional Meeting of the World Medical Association. 7 Nov 2017. https://w2.vatican.va/content/francesco/en/messages/pont-messages/2017/ documents/papa-francesco_20171107_messaggio-monspaglia.html.

Published by the BMJ Publishing Group Limited. For permission to use (where not already granted under a licence) please go to http://group.bmj.com/group/rights-licensing/ permissions 
